\title{
\begin{tabular}{l|l} 
Jurnal Eksplorasi Akuntansi \\
Vol. 1, No 3, Seri D, Agustus 2019, Hal 1275-1292
\end{tabular} \mid $\begin{aligned} & \text { ISSN : 2656-3649 (Online) } \\
& \text { http://jea.ppj.unp.ac.id/index.php/jea/issue/view/11 }\end{aligned}$
}

\section{PENGARUH FISCAL STRESS, VARIANS ANGGARAN DAN PERUBAHAN SISA LEBIH PERHITUNGAN ANGGARAN TERHADAP PERUBAHAN ANGGARAN BELANJA PADA PEMERINTAH DAERAH (Studi Empiris Pada Pemerintah Daerah Kabupaten/Kota Di Provinsi Sumatera Barat)}

\author{
Arief Kurniawan', Fefri Indra Arza ${ }^{2}$ \\ 1)Alumni Jurusan Akuntansi Fakultas Ekonomi Universitas Negeri Padang \\ ${ }^{2)}$ Jurusan Akuntansi Fakultas Ekonomi, Universitas Negeri Padang \\ *Korespondensi: ariefcra@gmail.com
}

\begin{abstract}
The objective of this study is to determine the effect of fiscal stress, budget variances, and rebudgeting in time over budget calculation (SiLPA) to budget expenditure change on local government in West Sumatera. The sample of this study using the 19 districts/cities in West Sumatera period of 2013-2017. Sampling was done by using total sampling method. The type of data used is secondary data obtained from local regulation data on rebudgeting in revenue and expenditure (P-APBD), then data in local government financial report (LKPD). The analytical method used is panel regression analysis models were performed with Eviews10. Results of regression testing showed that only rebudgeting in SiLPA which effect positive and significant to budget expenditure change, while fiscal stress and both of budget variances (revenue variance and expenditure variance) does not significantly effect to budget expenditure change on local government (districts/cities) in West Sumatera period of 2013-2017.
\end{abstract}

Keywords: Budget expenditure change, fiscal stress, budget variances, rebudgeting in time over calculation (SiLPA).

How to cite (APA 6th style)

Kurniawan, A., \& Arza, F.I. (2019). Pengaruh Fiscal Stress, Varians Anggaran dan Perubahan Sisa Lebih Perhitungan Anggaran terhadap Perubahan Anggaran Belanja pada Pemerintah daerah (Studi Empiris pada Pemerintah Daerah Kabupaten/Kota di Provinsi Sumatera Barat Tahun 2013-2017). Jurnal Eksplorasi Akuntansi, 1(3), Seri D, 1275-1292.

\section{PENDAHULUAN}

Anggaran di sektor publik yang disebut dengan Anggaran Pendapatan dan Belanja Daerah (APBD) menurut Peraturan Pemerintah Republik Indonesia Nomor 58 Tahun 2005 adalah rencana keuangan pemerintahan daerah yang dibahas serta disetujui bersama oleh pemerintah daerah dan Dewan Perwakilan Rakyat Daerah (DPRD) untuk masa berlaku selama satu tahun anggaran, dan kemudian ditetapkan dengan peraturan daerah. Penyusunan rancangan APBD berpedoman kepada rencana kerja pemerintah daerah dalam rangka tercapainya tujuan bernegara. Penyusunan rencana kerja dalam rancangan APBD dilakukan setahun sebelum 
pelaksanaannya, maka kemungkinan besar akan terjadi penyesuaian selama tahun berjalan. Dalam satu periode anggaran yang telah disusun tidak sepenuhnya dapat menangkap kebutuhan suatu organisasi sehingga dimungkinkan untuk dilakukan perubahan anggaran (rebudgeting) (Abadiarti, 2014).

Perubahan anggaran (rebudgeting), menurut Forrester dan Mullins (1992), adalah konsekuensi atas terjadinya perbedaan antara jumlah anggaran yang direncanakan sebelumnya dengan yang dibutuhkan pada kondisi terkini. Perubahan anggaran tidak disajikan didalam Laporan Keuangan Pemerintah Daerah (LKPD), hal tersebut menyebabkan sebagian besar masyarakat tidak mengetahui perubahan anggaran yang terjadi dalam APBD, sehingga masyarakat tidak dapat mengawasi secara efektif pelaksanaan APBD. Kecenderungan daerah untuk melakukan perubahan anggaran pada saat menjelang akhir tahun berjalan (setelah September) adalah salah satu alasan mengapa proses penganggaran tampaknya tidak berjalan secara efektif dalam menyelesaikan masalah di masyarakat dan pemerintahan (Muda, 2017).

Menurut Peraturan Pemerintah Republik Indonesia Nomor 58 Tahun 2005 tentang pengelolaan keuangan daerah, perubahan atas APBD tahun anggaran yang bersangkutan dapat terjadi apabila: a) perkembangan yang tidak sesuai dengan asumsi kebijakan umum APBD, b) keadaan yang menyebabkan harus dilaksanakan pergesaran anggaran antar unit organisasi, antar kegiatan, dan antar jenis belanja, c) keadaan yang menyebabkan saldo anggaran lebih tahun sebelumnya harus digunakan untuk tahun berajalan, d) keadaan darurat, serta e) keadaan luar biasa.

Perubahan anggaran dapat berupa penambahan dan pengurangan atas pendapatan, belanja, atau pembiayaan. Dengan adanya perubahan tersebut diharapkan akan meningkatkan kinerja dan kualitas anggaran pemerintah daerah. Perubahan anggaran yang difokuskan dalam penelitian ini adalah perubahan anggaran belanja karena merupakan perubahan yang paling penting dalam penganggaran di sektor publik, khususnya pemerintahan (Forrester \& Mullins, 1992). Perubahan anggaran belanja menyatakan gambaran dari perubahan target pelayanan publik dan orientasi pembangunan daerah dalam periode anggaran tertentu (jangka pendek). Perubahan tersebut dapat terjadi karena adanya transformasi perkiraan pendapataan dan penerimaan pembiayaan daerah (Abdullah \& Rona, 2016).

Perubahan APBD merupakan program yang dilakukan secara rutin oleh pemerintah daerah, sebagai upaya untuk menjalankan penyesuaian yang terjadi. Di provinsi Sumatera Barat khususnya, perubahan anggaran dilakukan oleh pemerintah kota Padang pada tahun 2017 dengan dilaksanakannya penggeseran karena adanya pemangkasan anggaran sebesar Rp.121 miliar (PadangMedia). Pada tahun 2018, DPRD Sumatera Barat juga kebut APBD perubahan karena rendahnya realisasi belanja langsung dan belanja tidak langsung, yakni terhitung 38,73 persen dan 27,19 persen hingga akhir semester pertama (Singgalang). Dari fenomena tersebut, dapat dinyatakan bahwa perubahan anggaran belanja merupakan komponen yang relatif paling sering berubah, yang menggambarkan adanya perubahan kebijakan anggaran yang dilakukan oleh pemerintah daerah. Dikarenakan dokumen perubahan APBD hanya berupa peraturan daerah dan tidak ditampilkan di dalam LKPD maka faktor-faktor yang mempengaruhi perubahan anggaran perlu diteliti agar tercipta APBD yang efektif dan dapat memberikan manfaat bagi masyarakat.

Beberapa penelitian mengenai perubahan anggaran (rebudgeting) diantaranya adalah Anessi dan Sicilia (2012) yang melakukan penelitian mengenai budgeting dan rebudgeting dengan sampel kota di Italia menguji hipotesis mengenai faktor penyebab dari pelaksanaan perubahan anggaran. Hasilnya menunjukkan bahwa perubahan anggaran sangat dipengaruhi oleh tingkat incrementalism dalam proses penyusunan anggaran awal, serta oleh beberapa faktor 
internal dan eksternal diantaranya variabel politik, fitur organisasi, kondisi keuangan pemerintah, dan lingkungan sosioekonomi setempat.

Kondisi keuangan pemerintah daerah dan sumber daya yang tidak memadai merupakan salah satu faktor penyebab yang mempengaruhi perubahan anggaran (Lu dan Facer, 2004). Kondisi keuangan yang seperti ini akan menyebabkan daerah mengalami tekanan fiskal (fiscal stress). Junita dan Abdullah (2016), yang melakukan penelitian tentang pengaruh fiscal stress terhadap perubahan anggaran belanja di kabupaten dan kota di Sumatera Utara, menyatakan bahwa telah terjadi ketimpangan kapasitas fiskal yang tinggi antar daerah. Beberapa daerah yang memiliki sumber penerimaan yang memadai, tidak akan mengalami masalah fiskal. Namun, bagi daerah lain yang tidak memiliki sumber penerimaan yang memadai serta sumber daya yang terbatas, otonomi akan menimbulkan persoalan tersendiri karena adanya tuntutan bagi daerah untuk meningkatkan kemandirian daerahnya. Implikasi dari keadaan tersebut mendorong pemerintah daerah untuk melakukan perubahan anggaran.

Junita et al (2018) yang melakukan penelitian tentang pengaruh varians anggaran terhadap perubahan anggaran di kabupaten dan kota di Aceh menyatakan bahwa varians pendapatan dan varians pengeluaran berpengaruh negatif terhadap perubahan anggaran belanja. Varians pendapatan adalah keakuratan dalam penentuan target pendapatan, sedangkan varians pengeluaran adalah keakuratan perhitungan atas kebutuhan sumber daya untuk menjalankan fungsi pemerintahan daerah dan pelayanan publik.

Costello (2012) menjelaskan bahwa pemerintah daerah dapat membuat perubahan ke arah pengeluaran untuk tahun anggaran berikutnya jika kegiatannya tidak dapat didanai dalam anggaran saat ini. Penelitian sejenis telah dilakukan oleh Abdullah (2014) yang menguji pengaruh perubahan Sisa Lebih Perhitungan Anggaran (SiLPA), perubahan Pendapatan Asli Daerah (PAD), dan perubahan Dana Bagi Hasil (DBH) terhadap perubahan anggaran Belanja Barang dan Jasa (BBJ). Hasilnya menunjukkan bahwa hanya variabel perubahan SiLPA yang berpengaruh signifikan terhadap perubahan anggaran BBJ, sedangkan perubahan anggaran PAD dan perubahan anggaran DBH tidak berpengaruh signifikan terhadap perubahan anggaran BBJ.

Penelitian ini mencoba untuk mengetahui faktor-faktor yang mempengaruhi perubahan anggaran belanja daerah pada pemerintah kab/kota di Sumatera Barat. Faktor-faktor yang digunakan dalam penelitian ini diantaranya fiscal stress, varians anggaran yang terdiri atas varians pendapatan dan varians belanja, serta Perubahan Sisa Lebih Perhitungan Anggaran (PSiLPA).Perbedaan penelitian ini dengan penelitian sebelumnya adalah penelitian ini secara khusus mengambil sampel pemerintahan kabupaten dan kota di Sumatera Barat, dengan menggunakan data time series dari tahun 2013-2017.

Tujuan dari penelitian ini untuk memberikan bukti empiris mengenai pengaruh fiscal stress, varians anggaran, dan Perubahan Sisa Lebih Perhitungan Anggaran (P-SiLPA) terhadap peubahan anggaran belanja daerah, pada pemerintah daerah kab/kota di provinsi Sumatera Barat tahun 2013-2017.

\section{REVIU LITERATUR DAN HIPOTESIS Teori Keagenan}

Hubungan keagenan di dalam teori agensi menurut Jensen dan Meckling (1976) merupakan kumpulan kontrak antara principal sebagai pemilik sumber daya dengan agent yang diberikan wewenang untuk mengurus penggunaan dan pengendalian sumber daya tersebut. Implikasi teori keagenan tidak hanya dalam lingkupan organisasi sektor swasta, namun juga sektor publik, khususnya pemerintahan. 
Pelaksanaan anggaran dan perubahan anggaran di sektor pemerintahan merupakan konsep dari teori keagenan.Halim dan Abdullah (2006), dari perspektif teori keagenan, menyatakan bahwa perda tentang Anggaran Pendapatan dan Belanja Daerah (APBD) dan perubahan APBD merupakan suatu bentuk kontrak antara principal (legislatif) dengan agent (eksekutif). Dewan Perwakilan Rakyat Daerah (DPRD) atau legislatif memberi kewenangan kepada kepala daerah (eksekutif) untuk melaksanakan dan mempertanggungjawabkan anggaran yang sudah ditetapkan tersebut.

Eksekutif selaku agent memiliki kecenderungan dalam penyusunan anggaran dengan mempertimbangkan self-interest nya. Sedangkan legislatif selaku principal yang menyetujui kebijakan yang ditetapkan oleh pemerintah atas nama rakyat yang diwakilinya.

\section{Anggaran}

Jones (2012) menyimpulkan bahwa anggaran merupakan suatu bentuk dari kerja pemerintah yang diwujudkan dalam bentuk mata uang rupiah selama masa periode tertentu (umumnya 1 tahun). Anggaran tersebut berguna sebagai sarana untuk menentukan besarnya pengeluaran, membantu dalam pengambilan keputusan, perencanaan pembangunan, otorisasi pengeluaran dimasa mendatang, standar evaluasi kinerja masa lalu, alat memotivasi para pegawai, dan sebagai alat koordinasi bagi semua aktivitas dari berbagai unit kerja (Abadiarti, 2014).Anggaran juga dapat diartikan sebagai paket pernyataan mengenai perkiraan penerimaan dan pengeluaran yang diharapkan akan terjadi dalam satu atau beberapa periode mendatang. Dalam anggaran selalu dicantumkan data penerimaan dan pengeluaran yang terjadi di masa lalu (Bastian, 2010).

\section{Anggaran Pendapatan dan Belanja Daerah (APBD)}

Mardiasmo (2012) menyatakan bahwa APBD adalah suatu rencana kerja pemerintah daerah yang mencakup seluruh pendapatan atau penerimaan dan belanja atau pengeluaran pemerintah daerah, baik provinsi, kabupaten, dan kota dalam rangka mencapai sasaran pembangunan dalam kurun waktu satu tahun yang dinyatakan dalam satuan uang yang disetujui oleh DPRD dalam peraturan perundangan yang disebut peraturan daerah. APBD terdiri atas anggaran pendapatan daerah, anggaran belanja daerah, dan pembiayaan.

\section{Perubahan Anggaran}

Anggaran yang telah direncanakan tahun sebelumnya dalam pelaksanaannya dihadapkan dengan perkembangan yang ada sehingga dibutuhkan perubahan atau revisi agar dapat memenuhi kebutuhan masyarakat. Perubahan APBD diharapkan dapat menjamin tercapainya program pemerintahan sebagaimana dengan yang ditetapkan sebelumnya. Perubahan APBD juga dimaksudkan untuk memanfaatkan perubahan (khususnya kenaikan) pendapatan selama tahun anggaran berjalan, sehingga pada akhir tahun tidak menyisakan dana anggaran yang besar (Sari dan Abdullah, 2017).

Abdullah dan Nadir (2014), menyimpulkan bahwa perubahan anggaran dapat memberikan perlindungan nilai terhadap ketidakpastian dan merasionalisasikan anggaran di saat kondisi yang tidak menentu. Selama periode pendapatan dan pengeluaran, perubahan anggaran dapat dimanfaatkan sebagai sarana penyesuai kebijakan. Perubahan APBD didorong oleh permasalahan teknis. Setiap daerah melaksanakan perubahan APBD untuk menyesuaikan program yang telah ditetapkan sebelumnya dengan anggaran, serta untuk memenuhi kebutuhan terhadap kondisi ataupun lingkungan yang berubah. 


\section{Perubahan Anggaran Belanja Daerah}

Anggaran belanja daerah menurut Permendagri No. 21 Tahun 2011 tentang pedoman pengelolaan keuangan daerah adalah bagian dari kewajiban-kewajiban pemerintah daerah yang diakui sebagai pengurang nilai kekayaan bersih. Sedangkan menurut Sharkansky dalam Abdullah \& Rona (2016), anggaran belanja dapat dinyatakan sebagai indikator kualitas pelayanan publik yang dapat diberikan dan prioritas pembangunan yang telah direncanakan oleh pemerintah.

Perubahan anggaran belanja merupakan perubahan yang paling penting dalam penganggaran di sektor publik, khususnya pemerintahan (Forrester \& Mullins, 1992). Perubahan anggaran belanja menyatakan gambaran dari perubahan target pelayanan publik dan orientasi pembangunan daerah dalam periode anggaran tertentu (jangka pendek). Perubahan tersebut dapat terjadi karena adanya transformasi perkiraan pendapataan dan penerimaan pembiayaan daerah (Abdullah \& Rona, 2016).

\section{Fiscal Stress}

Fiscal stress merupakan tekanan fiskal (keuangan) yang terjadi ketika penerimaan (pendapatan) tidak mampu menutupi pengeluaran (belanja) yang dilakukan daerah. Havesi (2006) menyatakan bahwa fiscal stress merupakan penilaian tentang kondisi keuangan yang pada umumnya masyarakat mengalami keterbatasan terhadap pembiayaan operasi, dan mengalami masalah pertumbuhan anggaran.

Fiscal stress bisa terjadi ketika dilaksanakannya otonomi daerah, dengan harapan dapat meningkatkan kemandirian karena daerah tidak lagi memiliki ketergantungan dengan pemerintah pusat. Sebagaimana yang dinyatakan oleh Nanga dalam Muda (2012), bahwa disparitas (kapasitas) fiskal yang tinggi antar daerah akan muncul ketika memasuki era otonomi. Karena tidak semua daerah memiliki sumber-sumber penerimaan daerah yang memadai seperti penerimaan yang berasal dari pajak daerah, retribusi daerah dan juga pendapatan lainnya yang sah (pendapatan asli daerah).

\section{Varians Anggaran}

Varians anggaran merupakan selisih antara target dan realisasi anggaran. Selisih antara anggaran dan realisasi menunjukkan ketidak-akuratan dalam penetapan target anggaran pada proses penyusunan anggaran (Abdullah dan Nazry, 2014). Varian anggaran dibagi menjadi dua yaitu varians pendapatan dan varians belanja. Varians anggaran (pendapatan dan belanja) yang terjadi menunjukkan ramalan awal yang buruk pada saat penyusunan anggaran awal tahun. Varians anggaran juga menunjukkan bagaimana kinerja keuangan pemerintah daerah. Kinerja yang baik menunjukkan realisasi pendapatan yang lebih besar atau setidaknya sama dengan anggaran pendapatan. Begitu sebaliknya, kinerja yang baik menunjukkan realisasi belanja yang lebih kecil atau setidaknya sama dengan anggaran belanja.

\section{Varians Pendapatan}

Varians pendapatan merupakan selisih antara anggaran pendapatan dan realisasi pendapatan pada akhir tahun. Junita et al (2018), menyatakan bahwa dalam pelaksanaan anggaran, jumlah perkiraan awal anggaran (pendapatan) tidak akan sama dengan nilai aktual atau jumlah realisasi pada akhir tahun, dimana menghasilkan perbedaan yang disebut varians pendapatan.Varians pendapatan yang besar menunjukkan ramalan pendapatan yang buruk. 


\section{Varians Belanja}

Varians pengeluaran (belanja) merupakan selisih antara anggaran belanja dan realisasi belanja pada akhir tahun. Varians belanja terjadi ketika target belanja tidak tercapai pada saat realisasi akhir tahun. Junita et al (2018) membagi varians anggaran menjadi dua, yaitu 1) varians untuk pengeluaran (belanja) rutin atau operasional yang dilakukan terus menerus. dan 2) varians untuk belanja modal atau pengembangan, dimaksudkan untuk membiayai proses penyediaan fasilitas, infrastruktur, dan aset lainnya yang digunakan oleh pemerintah daerah dalam beberapa tahun anggaran.

\section{Perubahan Sisa Lebih Perhitungan Anggaran (P-SiLPA)}

Sisa Lebih Perhitungan Anggaran (SiLPA) merupakan selisih lebih realisasi penerimaan dan pengeluaran (belanja) anggaran selama satu periode anggaran.Besaran sisa anggaran tahun sebelumnya masih berupa ramalan dikarenakan penetapan anggaran untuk periode tahun sekarang (periode t) dilakukan sebelum pertanggungjawaban atas pelaksanaan anggaran untuk tahun anggaran periode sebelumnya (periode t-1) selesai. Berarti sisa anggaran periode tahun sebelumnya (periode t-1) belum dapat dipastikan sehingga jumlah nya akan berbeda dengan yang sesungguhnya. Akibat perbedaan ini, timbul kebutuhan untuk melakukan penyesuaian anggaran ketika jumlah yang sebenarnya telah diketahui (Abdullah \& Rona, 2014).

Nelliyanti et al (2016) menyatakan bahwa SiLPA adalah penerimaan pada awal tahun berjalan yang berasal dari realisasi Sisa Lebih Pembiayaan (SILPA) tahun sebelumnya yang menjadi salah satu objek untuk perubahan anggaran dalam tahun berjalan, terutama dalam bentuk penyesuaian untuk belanja. Jumlah SiLPA yang diakui pada saat penyusunan APBD tersebut masih bersifat ramalan dikarenakan a) belum semua pertanggungjawaban disampaikan oleh Satuan Kerja Perangkat Daerah (SKPD) kepada Bendahara Umum Daerah (BUD) pada akhir tahun anggaran lalu dan b) Badan Pemeriksa Keuangan (BPK) belum melaporkan bahwa jumlah SiLPA sudah sesuai dengan yang sesungguhnya (Abdullah dan Nadir, 2014).

\section{Pengembangan Hipotesis \\ Pegaruh Fiscal Stress terhadap Perubahan Anggaran Belanja Daerah}

Fiscal stress merupakan tekanan anggaran yang terjadi ketika pemerintah daerah tidak mampu menyeimbangkan anggaran tahunan dengan transaksi berjalan.Junita dan Abdullah (2016), menyatakan bahwa fiscal stress (tekanan fiskal) yang tinggi menunjukkan kemampuan pemerintah daerah yang rendah dalam menyesuaikan anggarannya, jadi besar kemungkinan dilakukan perubahan terhadap anggaran (khususnya belanja). Keadaan ini mencerminkan rendahnya kemampuan daerah untuk membiayai semua kebutuhan daerah yang menjadi tanggungjawabnya. Semakin tinggi tingkat fiscal stress, maka semakin besar pula perubahan anggaran belanja yang akan dilakukan oleh pemerintah daerah.

H1: Fiscal stress berpengaruh positif terhadap perubahan anggaran belanja daerah

\section{Pengaruh Varians Anggaran terhadap Perubahan Anggaran Belanja Daerah}

Varian pendapatan timbul dari perbedaan antara arus kas masuk yang diharapkan dengan arus kas masuk aktual dalam satu peiode anggaran. Menurut penelitian Junita et al (2018), varians pendapatan menunjukkan ketidakefektifan penetapan target anggaran saat penyusunan anggaran. Ketika pendapatan dinaikkan, maka kelebihan target yang telah ditentukan akan menjadi varian anggaran, kelebihan kas pada target akan menjadi sumber pembiayaan pada anggaran peiode berikutnya. 
Varians pengeluaran (belanja) menyisihkan dana ketika realisasi pengeluaran berada dibawah target (anggaran). Sisa anggaran (varians) tahun sebelumnya dapat digunakan untuk tahun berjalan dengan dilakukan perubahan anggaran. Menurut penelitian Junita et al (2018), varians anggaran adalah indikator kinerja anggaran tahun sebelumnya, maka varians anggaran dapat digunakan sebagai prediktor untuk perubahan anggaran tahun berikutnya. Semakin tinggi nilai varians anggaran (varians pendapatan dan belanja) berarti sisa anggaran tahun lalu yang akan dibawa untuk anggaran tahun sekarang semakin besar jumlahnya, maka perubahan terhadap anggaran belanja akan lebih rendah.

$\mathbf{H}_{2}$ : Varians pendapatan berpengaruh negatif terhadap perubahan anggaran belanja daerah

$\mathbf{H}_{3}$ : Varians belanja berpengaruh negatif terhadap perubahan anggaran belanja daerah

\section{Pengaruh Perubahan Sisa Lebih Perhitungan Anggaran (PSiLPA) terhadap Perubahan Anggaran Belanja Daerah}

Sisa Lebih Perhitungan Anggaran (SiLPA) adalah sisa lebih pembiayaan anggaran tahun lalu. SiLPA merupakan penerimaan pada awal tahun berjalan. Menurut Martunis (2014), SiLPA merupakan salah satu prediktor perubahan anggaran. Anggaran yang berlebih periode sebelumnya dapat digunakan untuk pembiayaan periode berikutnya. Besaran sisa anggaran tahun sebelumnya masih berupa ramalan dikarenakan penetapan anggaran untuk periode tahun sekarang (periode t) dilakukan sebelum pertanggungjawaban atas pelaksanaan anggaran untuk tahun anggaran periode sebelumnya (periode t-1) selesai. Berarti sisa anggaran periode tahun sebelumnya (periode t-1) belum dapat dipastikan sehingga jumlahnya akan berbeda dengan yang sesungguhnya. Akibat perbedaan ini, timbul kebutuhan untuk melakukan penyesuaian anggaran ketika jumlah pastinya sudah diketahui (Abdullah dan Rona, 2014). Semakin besar perubahan SiLPA maka semakin besar perubahan anggaran belanja untuk memaksimalkan anggaran berlebih.

$\mathrm{H}_{4}$ : Perubahan Sisa Lebih Perhitungan Anggaran (P-SiLPA) berpengaruh positif terhadap perubahan anggaran belanja daerah

\section{Kerangka Konseptual}

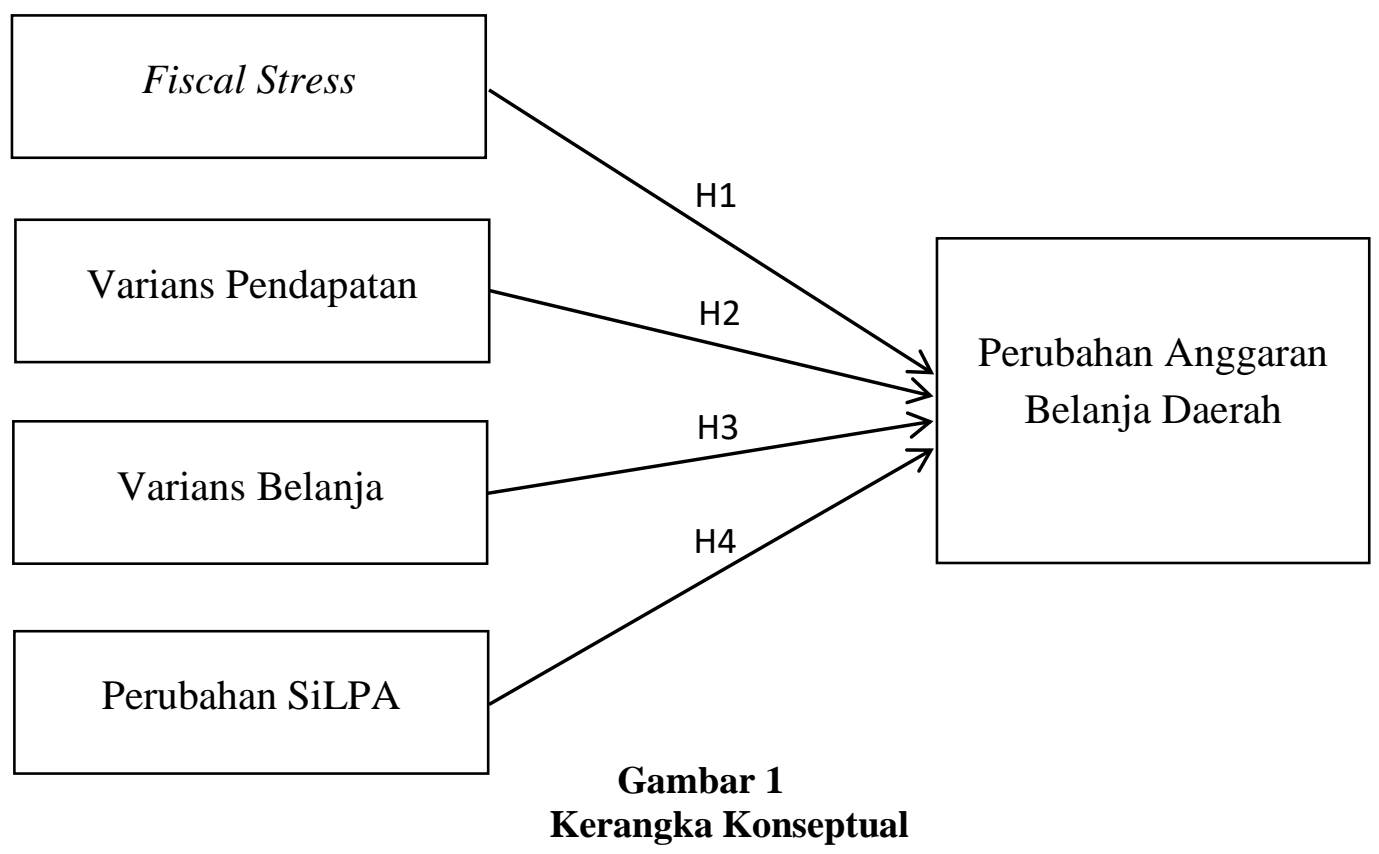




\section{METODE PENELITIAN}

Jenis penelitian ini adalah penelitian asosiatif kausal. Jenis data adalah data sekunder. Data dalam penelitian ini berasal dari peraturan daerah kabupaten/kota di Sumatera Barat tentang Perubahan Anggaran Pendapatan dan Belanja Daerah (P-APBD) yang diperoleh dari Badan Keuangan Daerah (BKD) pemerintah provinsi Sumatera Barat dan data Laporan Keuangan Pemerintah Daerah (LKPD) kabupaten/kota yang di peroleh dari Badan Pemeriksaan Keuangan Republik Indonesia (BPK RI).

Populasi dalam penelitian ini adalah seluruh pemerintah daerah kabupaten/kota di Sumatera Barat yang bejumlah 19 (sembilan belas) kabupaten/kota dari tahun 2013 - 2017 . Teknik pengambilan sampel dalam penelitian ini adalah menggunakan total sampling, dimana jumlah sampel yang digunakan sama dengan populasi yang akan diteliti. Teknik analisis data dalam penelitian ini menggunakan model regresi data panel. Data panel digunakan karena pada penelitian ini terdapa gabungan antara data time series dan data cross section. Jumlah total data dalam penelitian ini adalah 95. Model persamaan regresi panel dalam penelitian ini adalah sebagai berikut

$$
Y_{i t}=\alpha+\beta_{1} F S_{i t}+\beta_{2} V P_{i t}+\beta_{3} V B_{i t}+\beta_{4} P S i L P A_{i t}+\varepsilon_{i t}
$$

\section{Variabel Penelitian \& Pengukurannya}

Fiscal Stress

Fiscal stress merupakan tekanan fiskal (keuangan) yang terjadi ketika penerimaan (pendapatan) tidak mampu menutupi pengeluaran (belanja) yang dilakukan daerah. Fiscal stress bisa terjadi ketika dilaksanakannya otonomi daerah dengan harapan dapat meningkatkan kemandirian karena daerah tidak lagi memiliki ketergantungan dengan pemerintah pusat. Fiscal stress juga berarti keterbatasan penerimaan daerah. Di dalam penelitian ini pengukuran Fiscal Stress (FS) mengacu pada penelitian Arnett (2012) yaitu dengan membandingkan Pendapatan Asli Daerah (PAD) dengan total belanja daerah.

$$
F S=\frac{\text { PAD }}{\text { Total Belanja Daerah }}
$$

\section{Varians Anggaran}

Varians penerimaan (pendapatan) mengindikasikan bahwa dalam pelaksanaan anggaran, jumlah perkiraan awal anggaran penerimaan tidak akan sama dengan nilai aktual atau jumlah realisasi pada akhir tahun. Pada penelitian ini, pengukuran Varians Pendapatan (VP) mengacu pada penelitian Junita et al (2018) yaitu dengan menghitung selisih antara realisasi pendapatan dengan anggaran pendapatan tahun anggaran sebelumnya (periode t-1) dibagi anggaran belanja setelah perubahan tahun anggaran sekarang (periode $t$ ).

$$
V P=\frac{\text { Realisasi Pendapatan }(\mathrm{t}-1)-\text { Anggaran Pendapatan }(\mathrm{t}-1)}{\text { Anggaran Belanja PAPBD }(\mathrm{t})}
$$

Varians pengeluaran (belanja) mengindikasikan bahwa dalam pelaksanaan anggaran, jumlah perkiraan awal anggaran pengeluaran tidak akan sama dengan nilai aktual atau jumlah realisasi pada akhir tahun. pada penelitian ini, pengukuran Varians Belanja (VB) mengacu pada penelitian Junita et al (2018) yaitu dengan menghitung selisih antara realisasi belanja dengan anggaran belanja tahun anggaran sebelumnya (periode t-1) dibagi anggaran belanja setelah perubahan tahun anggaran sekarang (periode $\mathrm{t}$ ). 


$$
V B=\frac{\text { Realisasi Belanja }(\mathrm{t}-1)-\text { Anggaran Belanja }(\mathrm{t}-1)}{\text { Anggaran Belanja PAPBD }(\mathrm{t})}
$$

\section{Perubahan Sisa Lebih Perhitungan Anggaran (P-SiLPA)}

Sisa Lebih Perhitungan Anggaran (SiLPA) merupakan sisa lebih anggaran tahun lalu yang ada dalam Anggaran Pendapatan dan Belanja Daerah (APBD) tahun anggaran berjalan. Besaran SiLPA anggaran tahun lalu jumlahnya masih berupa ramalan karena ditetapkan sebelum pertanggungjawaban dan pelaksanaan anggaran tahun berjalan. Karena perbedaan ini, maka timbul kebutuhan untuk menyesuaikan angka SiLPA ketika jumlah pastinya sudah diketahui. Perubahan SiLPA (P-SiLPA) menurut penelitian Abdullah (2014) diukur dengan menghitung selisih antara angka SiLPA pada perubahan APBD dengan angka SiLPA pada APBD murni dibagi dengan angka SiLPA pada APBD murni.

$$
P-S i L P A=\frac{\text { SiLPA PAPBD }- \text { SiLPA APBD Murni }}{\text { SiLPA APBD Murni }}
$$

\section{HASIL DAN PEMBAHASAN}

\section{Statistik Deskriptif}

Digunakan untuk menganalisis serta mendeskripsikan data berdasarkan masing-masing variabel penelitian. Pada tabel 1 Analisis Deskriptif, diketahui rata-rata perubahan anggaran belanja daerah (PAB) adalah sebesar 0,0610, fiscal stress (FS) sebesar 0,0923, varians pendapatan (VP) sebesar $-0,0086$, varians belanja sebesar $-0,1071$, dan perubahan sisa lebih perhitungan anggaran sebesar 0,6998 .

Tabel 1

\begin{tabular}{|c|c|c|c|c|c|}
\hline \multicolumn{6}{|c|}{ Descriptive Statistics } \\
\hline Variabel & Mean & Median & Maximum & Minimum & $\begin{array}{c}\text { Std. } \\
\text { Deviasi }\end{array}$ \\
\hline PAB & 0,0610 & 0,0532 & 0,6611 & $-0,1321$ & 0,0912 \\
\hline FS & 0,0923 & 0,0809 & 0,2641 & 0,0376 & 0,0409 \\
\hline VP & $-0,0086$ & $-0,0035$ & 0,0433 & $-0,1255$ & 0,0229 \\
\hline VB & $-0,1071$ & $-0,0975$ & 0,1307 & $-0,2418$ & 0,0540 \\
\hline $\begin{array}{l}\text { P-SiLPA } \\
n=95\end{array}$ & 0,6998 & 0,3567 & 15,2919 & $-0,8063$ & 1,6837 \\
\hline
\end{tabular}

Statistik Deskriptif

(Sumber: Data Olahan Eviews10 tahun 2019)

\section{Analisis Model Regresi Panel}

Berdasarkan hasil Chow Test (Tabel 2) dan Lagrange Multplier Test (Tabel 3) menggunakan eviws 10: Hasil Estimasi Model Regresi panel, digunakan dalam penelitian ini adalah Common Effect Model (CEM). Serta, selanjutnya diperlukan uji asumsi klasik terhadap model penelitian ini (Hasil Uji Asumsi Klasik: (Tabel 4, Gambar 2, Tabel 5, dan Tabel 6) 
Tabel 2

Hasil Chow Test

\begin{tabular}{|c|c|c|c|}
\hline Effect Test & Statistic & d.f & Prob \\
\hline Cross Section Chi-square & 26,9720 & 18 & 0,0795 \\
\hline
\end{tabular}

Sumber: Data Olahan Eviews10 tahun 2019)

Tabel 3

Hasil Lagrange Multiplier Test

\begin{tabular}{|c|c|c|c|}
\hline \multicolumn{4}{|c|}{ Test Hypothesis } \\
\hline Model & $\begin{array}{l}\text { Cross- } \\
\text { section }\end{array}$ & Time & Both \\
\hline Breusch Pagan & $\begin{array}{c}0,2107 \\
(0,6462)\end{array}$ & $\begin{array}{c}0,7246 \\
(0,3946)\end{array}$ & $\begin{array}{c}0,9354 \\
(0,3335)\end{array}$ \\
\hline
\end{tabular}

(Sumber: Data Olahan Eviews10 tahun 2019)

Tabel 4

Hasil Uji Heteroskedastisitas

\begin{tabular}{|c|c|c|}
\hline \multicolumn{3}{|c|}{ Heterokedasticity Test } \\
\hline Model & Obs*R-squared & $\begin{array}{l}\text { Prob. Chi- } \\
\text { Square }\end{array}$ \\
\hline White & 1,1569 & 0,8851 \\
\hline
\end{tabular}

(Sumber: Data Olahan Eviews10 tahun 2019)

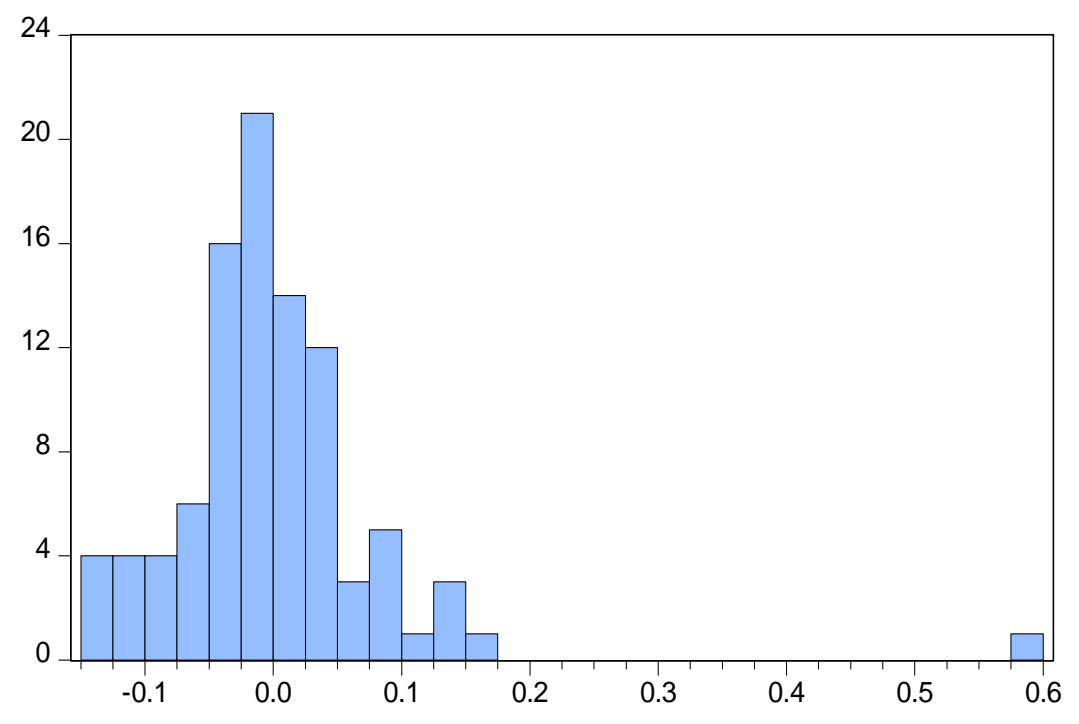

Series: Standardized Residuals

Sample 20132017

Observations 95

Mean $\quad-2.78 \mathrm{e}-17$

Median $\quad-0.008301$

Maximum $\quad 0.575772$

Minimum $\quad-0.149700$

Std. Dev. $\quad 0.086337$

Skewness $\quad 3.132212$

Kurtosis $\quad 22.22219$

Jarque-Bera $\quad 1617.912$

Probability $\quad 0.000000$

(Sumber: Data olahan Eviews10 tahun 2019)

Gambar 2

Hasil Uji Normalitas 
Tabel 5

Hasil Uji Multikolinearitas

\begin{tabular}{|l|cccc|}
\hline & FS & VP & VB & P-SiLPA \\
\hline FS & 1.0000 & $-0,2602$ & $-0,1199$ & $-0,0435$ \\
VP & $-0,2602$ & 1.0000 & 0,3742 & 0,0877 \\
VB & $-0,1199$ & 0,3742 & 1.0000 & 0,0494 \\
P-SiLPA & $-0,0435$ & 0,0877 & 0,0494 & 1.0000 \\
\hline
\end{tabular}

(Sumber: Data Olahan Eviews10 tahun 2019)

Tabel 6

\begin{tabular}{|c|c|}
\hline \multicolumn{2}{|c|}{$\begin{array}{c}\text { Iabel o } \\
\text { Hasil Uji Autokorelasi }\end{array}$} \\
\hline Model & Stat \\
\hline Durbin-Watson Test & 1,9999 \\
\hline
\end{tabular}

(Sumber: Data Olahan Eviews10 tahun 2019)

\section{Uji Signifikan}

Berdasarkan tabel 7 diketahui bahwa $F$-statistic signifikan pada 0,0407 yaitu lebih kecil dari signifikansi yang telah ditentukan dalam penelitian ini yaitu sebesar 0,05 . Hal ini menandakan bahwa model regresi panel diterima atau model ini menunjukkan tingkatan yang baik (good overall model fit) sehingga model regresi dapat digunakan. Dapat dijelaskan juga, secara simultan variabel independen berpengaruh signifikan terhadap variabel dependen.

Berdasarkan tabel 7 diketahui bahwa koefisien X1 fiscal stress bernilai negatif yaitu 0,3650 , dengan t-hitung sebesar $-1,5838$, dan tidak signifikan pada $\alpha 5 \%$ atau 0,05 . Hal ini berarti fiscal stress tidak berpengaruh signifikan terhadap perubahan anggaran belanja daerah sebab nilai signifikansi $>\alpha$ 0,05, yaitu 0,1168 >0,05. Serta t-hitung < t-tabel, yaitu $-1,5838<$ 1,98667. Berdasarkan tabel 7 diketahui bahwa koefisien X2 varians pendapatan bernilai positif yaitu 0,1334 , dengan t-hitung sebesar 0,3017 , dan tidak signifikan pada $\alpha 5 \%$ atau 0,05 . Hal ini berarti varian pendapatan tidak berpengaruh signifikan terhadap perubahan anggaran belanja daerah sebab nilai signifikansi $>\alpha 0,05$, yaitu $0,7637>0,05$. Serta t-hitung $<$ t-tabel, yaitu $0,3017<1,98667$.

Berdasarkan tabel 7 diketahui bahwa koefisien X3 varians belanja bernilai positif yaitu 0,0228 , dengan t-hitung sebesar 0,1253 , dan tidak signifikan pada $\alpha 5 \%$ atau 0,05 . Hal ini berarti varians belanja tidak berpengaruh signifikan terhadap perubahan anggaran belanja daerah sebab nilai signifikansi $>\alpha 0,05$, yaitu $0,9006>0,05$. Serta t-hitung $<\mathrm{t}$-tabel, yaitu $0,1253<1,98667$.

Berdasarkan tabel 7 diketahui bahwa koefisien X4 perubahan sisa lebih perhitungan anggaran bernilai positif yaitu 0,0140 , dengan t-hitung sebesar 0,0117 , dan signifikan pada $\alpha 5 \%$ atau 0,05 . Hal ini berarti perubahan sisa lebih perhitungan anggaran berpengaruh signifikan positif terhadap perubahan anggaran belanja daerah sebab nilai signifikansi $<\alpha 0,05$, yaitu $0,0140<0,05$. Serta t-hitung $>$ t-tabel, yaitu 2,5736 $>1,98667$. 
Tabel 7

Hasil Regresi Panel

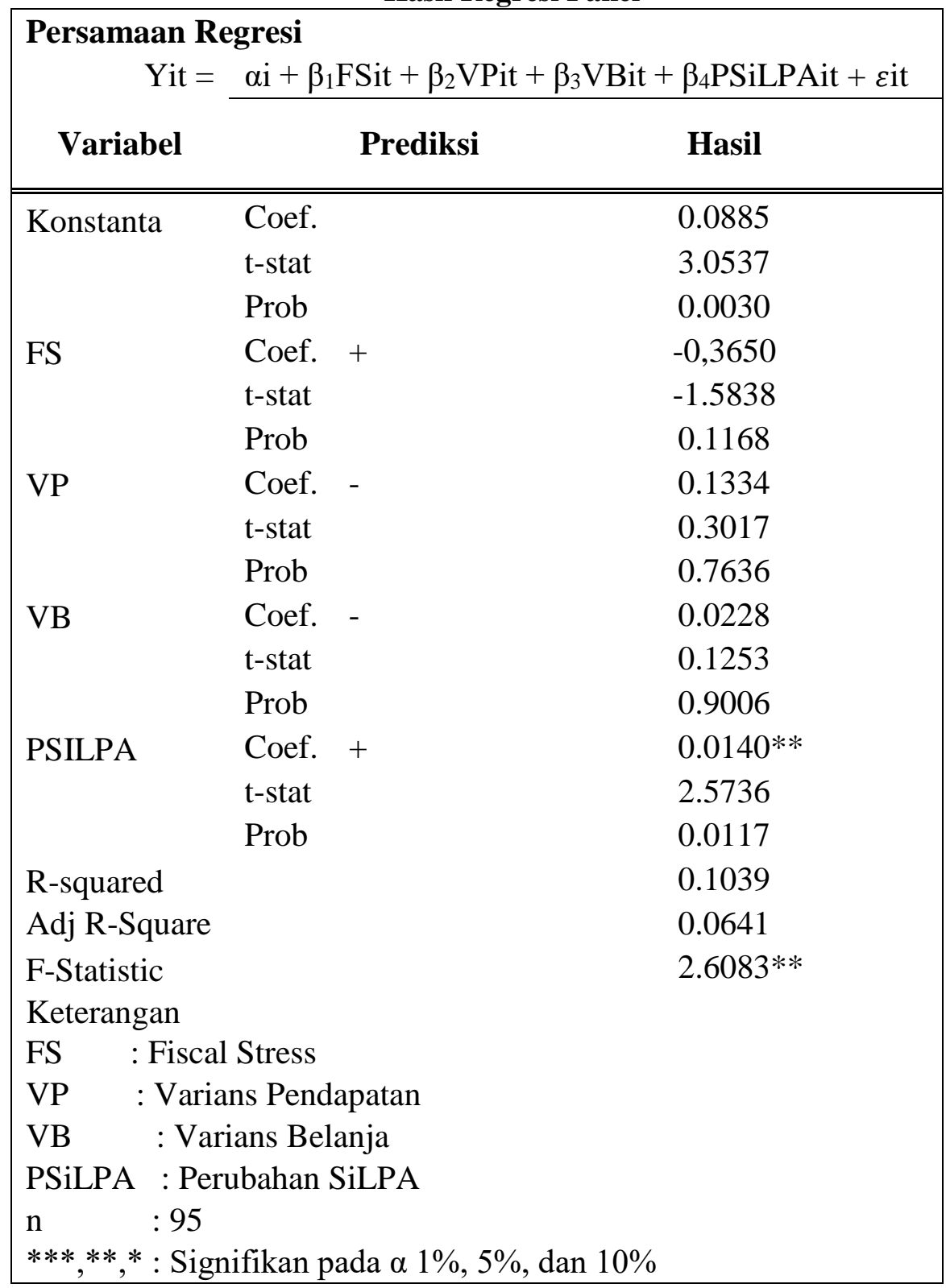

(Sumber: Data Olahan Eviews10 tahun 2019)

\section{Pembahasan}

\section{Pengaruh Fiscal Stress terhadap Perubahan Anggaran Belanja Daerah}

Berdasarkan hasil penelitian pada pemerintah daerah kabupaten/kota di provinsi Sumatera Barat pada tahun 2013-2017, ditemukan bahwa hipotesis (H1) ditolak, hal ini menggambarkan bahwa tingkat fiscal stress tidak berpengaruh signifikan terhadap perubahan anggaran belanja daerah. Hasil tersebut dapat dilihat dari tabel regresi panel sebelumnya, yang menunjukkan bahwa nilai signifikan dari variabel fiscal stress lebih besar dari $\alpha 0,05$, yaitu $0,1168>0,05$, serta nilai thitung yang $<\mathrm{t}$-tabel, yaitu $-1,583778<1,98667$.

Pengaruh yang tidak signifikan tersebut mengindikasikan bahwa besar kecilnya tingkat fiscal stress suatu daerah tidak menjadi alasan perubahan atas anggaran belanjanya pada 
pertengahan tahun akan dilakukan oleh pemerintah daerah. Fiscal stress atau yang disebut dengan tekanan fiskal merupakan gambaran kondisi keuangan pemerintah daerah yang kekurangan sumberdaya untuk memenuhi kebutuhan akan belanjanya. Fiscal stress akan menjadi semakin tinggi dikarenakan adanya tuntutan peningkatan kemandirian yang ditunjukkan dengan meningkatnya penerimaan sendiri (PAD) pada era otonomi untuk memenuhi belanja daerah tersebut.

Hasil analisis deskriptif sebelumnya menggambarkan bahwa rata-rata tingkat fiscal stress kabupaten/kota di provinsi Sumatera Barat adalah 9\%. Artinya, hanya sebesar 9\% belanja daerah dibiayai oleh pendapatan asli daerah tersebut. Hasil ini menjelaskan bahwa hampir semua daerah di provinsi Sumatera Barat mengalami tekanan fiskal karena pendapatan asli daerah (PAD) tidak mampu membiayai setengah dari belanja yang dilakukan daerah. Ini menunjukkan bahwa lebih dari 50\% belanja daerah akan dibiayai oleh dana perimbangan dari pemerintah pusat serta lainlainnya pendapatan daerah yang sah (Rani et al, 2010).

Hasil ini menunjukkan bahwa penerimaan daerah dari sumber PAD belum dapat membiayai kebutuhan rutin daerah, dan pemerintah daerah masih bergantung kepada pemerintah pusat. Sari dan Arza (2019) menyatakan salah satu karakteristik daerah yang mengalami financial distress adalah tingginya tingkat ketergantungan pada pemerintahan pusat. Berarti memang terbukti bahwa fiscal stress tidak berpengaruh terhadap perubahan anggaran belanja daerah, karena pemerintah daerah akan memaksimalkan alokasi dana perimbangan yang diterima dari pemerintah pusat. Perubahan anggaran belanja daerah pada pertengahan tahun mungkin akan terjadi apabila sumber penerimaan daerah dari PAD, dana perimbangan, serta lainnya pendapatan yang sah mengalami penurunan/berkurang. Penurunan tersebut secara otomatis akan membuat pemerintah daerah menyesuaikan anggaran belanjanya agar tidak terdapat defisit pada akhir tahun.

Hasil penelitian ini bertentangan dengan penelitian Junita dan Abdullah (2016) yang menemukan bahwa fiscal stress berpengaruh negatif terhadap perubahan anggaran belanja. Pada penelitian tersebut ditemukan bahwa tekanan fiskal yang tinggi mencerminkan kebutuhan belanja yang besar, namun tidak diikuti dengan kemampuan memperoleh pendapatan yang seimbang. Artinya, fleksibilitas pemerintah daerah dalam melakukan penyesuain untuk belanjanya rendah pada kondisi tekanan fiskal yang tinggi.

Berdasarkan hasil penelitian, dapat disimpulkan bahwa fiscal stress tidak berpengaruh terhadap perubahan anggaran belanja daerah. Terbukti bahwa pemerintah daerah tidak hanya bergantung kepada sumber PAD, tetapi juga kepada alokasi dana perimbangan dari pemerintah pusat dan lainnya pendapatan daerah yang sah.

\section{Pengaruh Varians Pendapatan terhadap Perubahan Anggaran Belanja Daerah}

Berdasarkan hasil penelitian pada pemerintah daerah kabupaten/kota di provinsi Sumatera Barat pada tahun 2013-2017, ditemukan bahwa hipotesis (H2) ditolak, hal ini menggambarkan bahwa varians pendapatan tidak berpengaruh signifikan terhadap perubahan anggaran belanja daerah. Hasil tersebut dapat dilihat dari tabel regresi panel sebelumnya, yang menunjukkan bahwa nilai signifikan dari variabel varians pendapatan lebih besar dari $\alpha 0,05$, yaitu $0,7637>0,05$, serta thitung < t-tabel, yaitu 0,301665 < 1,98667.

Pengaruh yang tidak signifikan tersebut mengindikasikan bahwa besar kecilnya selisih/varians pendapatan daerah tahun sebelumnya (t-1) tidak menjadi alasan perubahan anggaran atas belanjanya pada tahun sekarang (t) akan dilakukan oleh pemerintah daerah. Varians pendapatan merupakan selisih antara realisasi dengan anggaran awal tahunnya. Pada 
penetapan anggaran awal tahun, pendapatan akan cenderung dianggarkan lebih rendah dari kemampuan maksimalnya. Varians pendapatan juga dapat mengukur bagaimana kinerja anggaran pemerintah daerah tersebut.

Hasil analisis deskriptif sebelumnya juga menggambarkan ditolaknya hipotesis kedua ini, nilai rata-rata negatif dari analisis tersebut menggambarkan bahwa varians pendapatan tahun sebelumnya tidak memberikan pengaruh perubahan terhadap pelaksanaan anggaran belanja untuk pertengahan tahun sekarang. Varians pendapatan tahun sebelumnya akan dijadikan saldo awal kas pada tahun anggaran sekarang (Anessi-Pessina, 2012). Pada pembuatan anggaran tahun sekarang, penetapan tersebut menjadi kebijakan baru pemerintah daerah. Varians pendapatan yang mengindikasikan kinerja tahun sebelumnya menjadi salah satu kebijakan baru dalam penetapan anggaran awal, agar pada tahun berikutnya kinerja pemerintah akan semakin lebih baik bercermin dari bagaimana kinerja pemerintah daerah tahun sebelumnya khususnya dalam penganggaran. Semakin banyak kebijakan yang dimasukkan ke dalam penetapan penganggaran awal, maka perubahan anggaran pada pertengahan tahun tidak diperlukan lagi (Anessi-Pessina, 2012).

Hasil penelitian ini bertentangan dengan penelitian Junita et al (2018) yang menemukan bahwa varians pendapatan berpengaruh negatif terhadap perubahan anggaran belanja. Pada penelitian tersebut ditemukan bahwa varians pendapatan tahun sebelumnya yang besar akan menyebabkan selisihnya dibawa ke anggaran tahun sekarang juga akan semakin besar, maka perubahan anggaran belanja yang akan terjadi akan lebih kecil.

Berdasarkan hasil penelitian, dapat disimpulkan bahwa varians pendapatan tahun sebelumnya ( $\mathrm{t}-1)$ tidak berpengaruh terhadap perubahan anggaran belanja daerah pada tahun sekarang. Terbukti bahwa varians pendapatan tersebut mengindikasikan bagaimana kinerja pemerintah daerah tahun sebelumnya, dan akan menjadikan kebijakan baru dalam penetapan anggaran tahun sekarang. Artinya varians pendapatan ini bukanlah alasan bagi pemerintah daerah melakukan perubahan anggaran belanja untuk pertengahan tahun sekarang melainkan lebih kepada pengganggaran awal tahunnya.

\section{Pengaruh Varians Belanja terhadap Perubahan Anggaran Belanja Daerah}

Berdasarkan hasil penelitian pada pemerintah daerah kabupaten/kota di provinsi Sumatera Barat pada tahun 2013-2017, ditemukan bahwa hipotesis (H3) ditolak, hal ini menggambarkan bahwa varians belanja tidak berpengaruh signifikan terhadap perubahan anggaran belanja daerah. Hasil tersebut dapat dilihat dari tabel regresi panel sebelumnya, yang menunjukkan bahwa signifikan dari variabel varians belanja lebih besar dari $\alpha 0,05$, yaitu $0,9006>0,05$, serta t-hitung < t-tabel, yaitu $0,125287<1,98667$.

Pengaruh yang tidak signifikan tersebut mengindikasikan bahwa besar kecilnya selisih/varians belanja daerah tahun sebelumnya ( $t$-1) tidak menjadi alasan perubahan anggaran atas belanjanya pada tahun sekarang ( $\mathrm{t}$ ) akan dilakukan oleh pemerintah daerah. Varians belanja merupakan selisih antara realisasi dengan anggaran awal tahunnya. Pada penetapan anggaran awal, belanja akan cenderung dianggarkan lebih tinggi dari kemampuan maksimalnya. Sama halnya dengan varians pendapatan, varians belanja juga dapat mengukur bagaimana kierja pemerintah daerah tersebut.

Ditolaknya hipotesis ketiga ini didukung oleh hasil analisis deskriptif sebelumnya, dimana nilai rata-rata negatif menggambarkan bahwa varians belanja tahun sebelumnya tidak memberikan pengaruh perubahan terhadap pelaksanaan anggaran belanja untuk pertengahan tahun sekarang. Sama halnya varians pendapatan, varians belanja yang merupakan selisih dari 
anggaran tersebut akan menjadi saldo awal kas pada tahun sekarang apabila mengalami surplus anggaran yang mengindikasikan bagaimana kinerja pemerintah daerah pada tahun sebelumnya, dan ini menjadi patokan bagi pemerintah daerah dalam penganggaran awal tahun sekarang (Anessi-Pessina, 2012). Oleh karena itu varians tersebut tidak ada pengaruhnya terhadap perubahan anggaran belanja daerah pada pertengahan tahun.

Hasil penelitian ini bertentangan dengan penelitian Junita et al (2018) yang menemukan bahwa varians belanja berpengaruh negatif terhadap perubahan anggaran belanja. Pada penelitian tersebut ditemukan bahwa varians tahun sebelumnya yang besar akan menyebabkan selisihnya dibawa ke anggaran tahun sekarang juga akan semakin besar, maka perubahan anggaran belanja yang akan terjadi akan lebih kecil.

Berdasarkan hasil penelitian, dapat disimpulkan bahwa varians belanja tahun sebelumnya (t-1) tidak berpengaruh terhadap perubahan anggaran belanja daerah tahun sekarang. Terbukti bahwa varians belanja tersebut mengindikasikan kinerja pemerintah daerah tahun sebelumnya, dan akan menjadikan kebijakan baru dalam penetapan anggaran tahun sekarang. Artinya varians belanja ini bukanlah alasan bagi pemerintah daerah melakukan perubahan anggaran belanja untuk pertengahan tahun sekarang melainkan lebih ke penganggaran awal tahunya.

\section{Pengaruh Perubahan Sisa Lebih Perhitungan Anggaran terhadap Perubahan Anggaran Belanja Daerah}

Berdasarkan hasil penelitian pada pemerintah daerah kabupaten/kota di provinsi Sumatera Barat pada tahun 2013-2017, ditemukan bahwa hipotesis (H4) diterima, hal ini menggambarkan bahwa P-SiLPA berpengaruh positif terhadap perubahan anggaran belanja daerah, dimana semakin besar P-SiLPA maka akan semakin besar juga perubahan atas anggaran belanja daerah. Hasil tersebut dapat dilihat dari tabel regresi panel sebelumnya, yang menunjukkan bahwa signifikan dari varibel P-SiLPA lebih kecil dari $\alpha 0,05$, yaitu $0,0117<0,05$, serta t-hitung $>$ t-tabel, yaitu $2,573608>1,98667$.

Pengaruh yang positif dan signifikan, mengindikasikan bahwa pemerintah daerah yang memiliki nilai perubahan SiLPA yang besar akan meningkatkan perubahan anggaran belanja daerah pada pertengahan tahun untuk memaksimalkan anggaran berlebih tersebut. Perubahan SiLPA tersebut ada dikarenakan Sisa Lebih Pembiayaan Anggaran (SILPA) tahun sebelumnya yang dimasukkan ke SiLPA tahun berikutnya masih berupa perkiraan karena beberapa alasan salah satunya adalah belum dilakukan nya pertanggungjawaban atas anggaran tahun sebelumnya. Jadi, pada tahun berikutnya angka SiLPA pada anggaran awal dan angka SiLPA pada PAPBD akan berbeda. Makanya perubahan SiLPA ini akan dilakukan dan nantinya akan berpengaruh kepada perubahan anggaran belanja untuk memaksimalkan anggaran yang berlebih tersebut.

Hasil penelitian ini konsisten dengan penelitian Marzatilla et al (2014), Darwanis \& Abdullah (2014), dan Abdullah \& Rona (2014). Menurut Darwanis \& Abdullah (2014) yang melakukan penelitian di pemerintah daerah kabupaten/kota di Aceh, hasil penelitiannya membuktikan bahwa pemerintah daerah telah berhasil menggunakan SiLPA untuk pelaksanaan program/kegiatan pemerintah daerah kabupaten/kota dalam hal pelayanan publik. SiLPA diindikasikan menjadi salah satu sumber pendanaan belanja modal untuk pelayanan publik.

Berdasarkan hasil penelitian, maka dapat disimpulkan bahwa semakin besar tingkat perubahan SiLPA, maka akan semakin tinggi pula kemungkinan perubahan anggaran belanja daerah. Terbukti bahwa disaat perubahan SiLPA tinggi yang berarti anggaran yang tersisa berlebih maka pemerintah daerah akan melakukan perubahan anggaran belanja pada pertengahan tahun untuk memaksimalakan anggaran yang tersisa tersebut. 


\section{SIMPULAN, KETERBATASAN, DAN SARAN Simpulan}

Berdasarkan hasil temuan penelitian dan pengujian hipotesis yang diajukan sebelumnya dapat disimpulkan bahwa Hipotesis pertama ditolak, dimana fiscal stress tidak berpengaruh terhadap perubahan anggaran belanja daerah. Hal ini berarti besar atau kecilnya tingkat fiscal stress suatu daerah bukanlah menjadi alasan bagi pemerintah daerah untuk melakukan perubahan atas anggaran belanja daerahnya. Hipotesis kedua ditolak, dimana varians pendapatan tidak berpengaruh terhadap perubahan anggaran belanja daerah. Hal ini berarti besar atau kecilnya varians pendapatan tahun sebelumnya (t-1) bukanlah menjadi alasan bagi pemerintah daerah untuk melakukan perubahan anggaran belanja daerahnya untuk tahun sekarang (t). Hipotesis ketiga ditolak, dimana varians belanja tidak berpengaruh terhadap perubahan anggaran belanja daerah. Hal ini berarti besar atau kecilnya varians belanja tahun sebelumnya (t-1) bukanlah menjadi alasan bagi pemerintah daerah untuk melakukan perubahan anggaran belanja daerahnya untuk tahun sekarang (t). Hipotesis keempat diterima, dimana Perubahan Sisa Lebih Perhitungan Anggaran (P-SiLPA) berpengaruh positif dan signifikan terhadap perubahan anggaran belanja daerah. Hal ini berarti semakin besar (P-SiLPA) maka akan semakin besar perubahan anggaran belanja yang dilakukan oleh pemerintah daerah.

\section{Keterbatasan}

Keterbatasan dalam penelitian ini adalah Penelitian ini hanya dilakukan untuk sampel pemerintah daerah kabupaten/kota di provinsi Sumatera Barat. Sehingga, hasil penelitian tidak dapat direpresentasikan bagi pemerintah daerah di provinsi lainnya karena memungkinkan adanya perbedaan karakteristik pada masing-masing pemerintah daerah yang ada di Indonesia. Disamping itu, penelitian ini hanya mampu menjelaskan sebesar 6,4\% dari total variabel independen yang ada. Berarti sebesar 93,6\% sisanya dijelaskan oleh variabel independen lain yang tidak termasuk di dalam penelitian ini. Selanjutnya, penelitian ini hanya berfokus ke faktor kondisi keuangan pemerintah daerah yang diantaranya fiscal stress, varians anggaran, dan sisa lebih perhitungan anggaran.

\section{Saran}

Saran untuk penelitian selanjutnya adalah 1) Diharapkan dapat menggunakan sampel data untuk pemerintah daerah kabupaten/kota provinsi lainnya, atau dapat dilakukan penelitian dengan sampel cakupan pulau atau seluruh indonesia. 2) Diharapkan untuk menambah dan menguji faktor lainnya yang diduga dapat berpengaruh terhadap perubahan anggaran belanja, seperti faktor politik (ukuran legislatif) dan lainnya. 3) Diharapkan untuk mengembangkan data penelitian tidak hanya data sekunder dari perda perubahan APBD dan LKPD, tetapi juga dapat menggunakan data primer dengan menyebarkan kuisoner tertentu.

\section{DAFTAR PUSTAKA}

Abadiarti, Bertha. 2014. Pengaruh Tingkat Inkremental Penganggaran Awal, Kondisi Keuangan Pemerintah Daerah Dan Sosioekonomi Lokal Terhadap Rebudgeting Pada Pemerintah Daerah Di Indonesia (Studi Informasi Website Pemerintah Daerah). Tesis, Universitas Sebelas Maret, Surakarta. 
Abdullah, S., dan N. Nadir. 2014. "Analisis Faktor-Faktor Yang Berpengaruh Terhadap Perubahan Anggaran Belanja Satuan Kerja Perangkat Daerah". Jurnal Akuntansi Pascasarjana Universitas Syiah Kuala. pp 54-65.

Abdullah, S., dan R. Nazry. 2015. "Analisis Varian Anggaran Pemerintah Daerah Penjelasan Empiris dari Perspektif Keagenan”. Jurnal Samudra Ekonomi dan Bisnis 6 (2): 272-83.

Abdullah, S., dan R. Rona. 2014. "Pengaruh sisa anggaran, pendapatansendiri dan dana perimbangan terhadap belanja modal". IQTISHADIA (Journal of Islamic Economics and Business) 7 (1): 179-202. https://doi.org/10.21043/IQTISHADIA.V7I1.1106.

Anessi-Pessina, Eugenio, Mariafrancesca Sicilia, Ileana Steccolini. 2012 "Budgeting and Rebudgeting in Local Governments-Siamese Twins". Public Administration Review 72(6): 875-884.

Arnett, Sarah B, 2011. "Fiscal Stress in the US. States: An Analysis of Measures and Responses". George State University.

Bastian. Indra. 2010. Akuntansi Sektor Publik. Jakarta: Erlangga.

Christina, Happy. 2017. Variabel-Variabel yang Mempengaruhi Fiscal Stress Pemerintah Kabupaten di Indonesia. Skripsi. Universitas Lampung.

Costello, Anna M., Reining Petacchi, \& Joseph Weber. 2012. "The Hidden Consequences of Balanced Budget Requirements". Sloan School of Management, Massachusetts Institute of Technology. Working Paper.

Cornia, G. C., R. D. Nelson dan A. Wilko. 2004. "Fiscal Planning, Budgeting, and Rebudgeting Using Revenue Semaphores”. Public Administration Review, 64(2), 164 - 179

Erlina, Rasdianto. 2013. Akuntansi Keuangan Daerah Berbasis Akrual. Penerbit: Brama Ardian.

Forrester, J.P., Mullins, D.R. (1992). "Rebudgeting: The Serial Nature of Municipal Budgetary Processes". Public Administration Review 52(5): 467-473.

Ghozali, I. 2009.Aplikasi Analisis Multivariate dengan Program SPSS, Edisi. Keempat. Universitas Diponegoro.

Halim, A., Syukriy, A. 2006. "Hubungan dan Masalah Keagenan di Pemerintahan Daerah: Sebuah Peluang Penelitian Anggaran dan Akuntansi". Jurnal Akuntansi Pemerintah 2(1): 53-64

Hevesi, A.G. 2006. "Analysis of Fiscal Stress in New York State's Cities". Journal Division of Local Goverment Servies \& Economic Development. Volume 1. Nomor 2. Februari 2006.

Jones, R. 2012. "Budgetary Accounting in National Governments: Anglo versus American Accounting". Financial Accountability \& Management, 28(3), 286-305

Jensen, M., \& Meckling, W. 1976. "Theory of The Firm : Managerial Behavior, Agency Cost and Ownership Structure". Journal of Financial Economics 3, 305-360.

Junita, A., Syukriy, A. 2016. "Pengaruh Fiscal Stress dan Legislature Size terhadap Expenditure Change pada Kabupaten/Kota di Sumatera Utara". Jurnal Akuntansi 20(3): 477-478

Junita, A., Erlina, \& Abdullah Syukriy. 2018. "The Effect of Budget Variances on the Local Government Budget Changes with Legislature Size as moderator". Academic Journal of Economic Studies, 162-173

Kuncoro, Mudrajad. 2011. Metode Kuantitatif: Teori dan Aplikasi untuk Bisnis dan Ekonomi. Yogyakarta: UPP STIM YKPN.

Kusyanti, Y., Nadirsyah, dan A. Syukriy. 2014. "Analisis Faktor-Faktor yang Berpengaruh terhadap Perubahan Anggaran Belanja Satuan Kerja Perangkat Daerah: Studi pada Pemerintah Kabupaten Aceh Besar tahun 2010-2014”. Jurnal Akuntansi Pascasarjana Universitas Syiah Kuala 3 (2). 
Lu, H dan R. L. Facer. 2004. "Budget Change in Georgia Counties: Examining Patterns and Practise". American Review of Public Administration, 34(1), 67-93.

Mayper, A.G., Granof, M., Giroux, G. 1991. "An Analysis of Municipal Budget Variances”. Accounting, Auditing \& Accountability Journal 4(1): 29-50

Mardiasmo. 2012. Akuntansi Sektor Publik. Yogyakarta: Andi.

Martunis, Darwanis, Syukriy A. 2014. "Pengaruh Sisa Lebih Perhitungan Anggaran dan Pendapatan Asli Daerah terhadap Belanja Daerah: Analisis Perubahan APBD Kabupaten/Kota se-Aceh". Jurnal Akuntansi Pascasarjana Universitas Syiah Kuala 2(1): 1-8

Marzalita, N., dan S. Abdullah. 2014. "Faktor-Faktor yang Mempengaruhi Perubahan Anggaran Belanja Barang dan Jasa pada Pemerintah Daerah di Indonesia". Jurnal Administrasi Akuntansi: Program Pascasarjana Universitas Syiah Kuala 3 (3): 46-58.

Muda, Iskandar. 2012. "Variabel yang Mempengaruhi Fiscal Stress pada Kabupaten/Kota Sumatera Utara". Jurnal Keuangan \& Bisnis. Volume 4 Nomor 1.

Purwanto, Agus. 2016. "Pengaruh Kondisi Keuangan dan Politik terhadap Perubahan Anggaran pada Pemerintah Daerah di Indonesia”. Jurnal Akuntansi Dan Bisnis. Vol 16, 87-96.

Republik Indonesia. 2005. Peraturan Pemerintah Republik Indonesia No 58 Tahun 2005 Tentang Pengelolaan Keuangan Daerah. Jakarta: Pemerintah Indonesia.

Republik Indonesia. 2011. Peraturan Menteri Dalam Negeri Nomor 21 Tahun 2011 tentang Perubahan kedua Dari Peraturan Menteri Dalam Negeri Nomor 13 Tahun 2006 tentang Pedoman Pengelolaan Keuangan Daerah.

Republik Indonesia. 2014. Undang-Undang Republik Indonesia No 23 Tahun 2014 Tentang Pemerintah Daerah. Jakarta: Pemerintah Indonesia.

Republik Indonesia. 2003. Undang-Undang Republik Indonesia No 17 Tahun 2003 Tentang Keuangan Negara. Jakarta: Pemerintah Indonesia.

Rubin, Irene S. 1993. "The Politics of Public Budgeting: Getting and Spending, Borrowing and Balancing". Second edition. Chatam, NJ: Chatham House Publishers, Inc.

Sari, M., \& Arza, F. I. (2019). Pengaruh Karakteristik Pemerintah Daerah Terhadap Kondisi Financial Distress Pemerintah Daerah Kabupaten dan Kota Se-Indonesia Periode 20152017. Wahana Riset Akuntansi, 7(1).

Sekaran, U., 2013. Research Methods for Business. Chichester: John Wiley \& Son Ltd.

Setyawan, Budi, dan Priyo Hari Adi. 2002. "Pengaruh Fiscal stress terhadap Pertumbuhan Pendapatan asli Daerah dan Belanja Modal”. Disampaikan pada Simposium Nasional Riset Ekonomi \& Bisnis Asosiasi Perguruan Tinggi Katolik (APTIK)

Shamsub, H., Joseph B.A. 2004. "State and Local Fiscal Structure and Fiscal Stress". Journal of Public Budgeting, Accounting \& Financial Management; Spring 2004. International College of the Cayman Islands.

Sugiyono, (2008). Metode Penelitian Kuantitatif Kualitatif dan R\&D. Bandung Alfabeta.

Winarno, W. W. 2011. Analisis Ekonometrika dan Statistika dengan EViews. Edisi Ketiga, Cetakan pertama.UPP STIM YKPN.Yogyakarta 